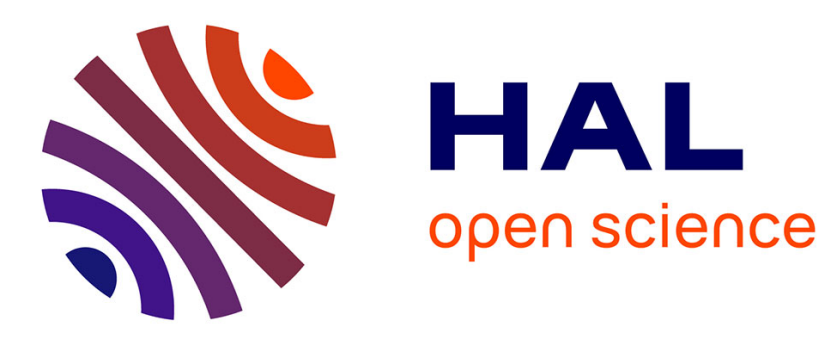

\title{
Direct/Inverse Systems
}

Guillaume Jacques, Anton Antonov

\section{To cite this version:}

Guillaume Jacques, Anton Antonov. Direct/Inverse Systems. Language and Linguistics Compass, 2014, 8, pp.301 - 318. 10.1111/lnc3.12079 . hal-01386706

\section{HAL Id: hal-01386706 https://hal.science/hal-01386706}

Submitted on 24 Oct 2016

HAL is a multi-disciplinary open access archive for the deposit and dissemination of scientific research documents, whether they are published or not. The documents may come from teaching and research institutions in France or abroad, or from public or private research centers.
L'archive ouverte pluridisciplinaire HAL, est destinée au dépôt et à la diffusion de documents scientifiques de niveau recherche, publiés ou non, émanant des établissements d'enseignement et de recherche français ou étrangers, des laboratoires publics ou privés. 


\title{
Direct/inverse systems
}

\author{
Guillaume JACQUES, Anton ANTONOV \\ CNRS-INALCO-EHESS, CRLAO
}

\section{Introduction}

The term 'inverse' has been used in the typological literature to designate a considerable variety of phenomena, which have been analyzed in several distinct frameworks. Direct-inverse systems are attested in a number of endangered languages spoken in the Americas (Algonquian, Mapudungun, Sahaptian etc) and the Himalayas (Sino-Tibetan).

The aim of this article is to provide an overview of direct/inverse systems in a perspective as free as possible from framework-specific assumptions, using the most recent data and adopting both a typological and a historical perspective. It is divided into four sections.

First, we propose a definition of the canonical direct/inverse system, and introduce the concepts of proximatelobviative and referential bierarcbies.

Second, we present examples of attested direct/inverse systems in the world's languages by subdividing them into two main categories: near-canonical and highly non-canonical, and additionally discussing systems with hierarchical agreement but without direction (direct/inverse) marking.

Third, we evaluate to what extent direct/inverse systems are correlated with other typological features.

Fourth, we apply a panchronic perspective on direct/inverse systems, studying their attested origin and their evolution, and how the diachronic pathways can help understand the present data.

\section{Basic definition}

Before defining the canonical direct/inverse system, we need to introduce some of the terminology used by typologists to describe systems which index two arguments. ${ }^{1}$ It is customary to represent these systems using semantic maps in tabular format as in Table 1, where rows indicate agent and columns patient. The different transitive configurations are symbolically represented by using an arrow, with the agent on its left and the patient on its right, both abbreviated as 1, 2, 3 for first,

\footnotetext{
*We would like to thank Sonia Cristofaro, Lynn Drapeau, Ives Goddard, Katharina Haude, Enrique Palancar, Géraldine Walther and two anonymous reviewers for useful comments on earlier versions of this article. We are responsible for any remaining errors. This research was funded by the HimalCo project (ANR-12-CORP-0006) and is related to the research strand LR-4.11 'Automatic paradigm generation and language description' of the Labex EFL (funded by the ANR/CGI).

${ }^{1}$ Indexation systems involving three arguments exist, but are rarer and will not be considered in this section.
} 
second and third person respectively. The first and second persons are called SPEECH ACT PARTICIPANTS (SAP). In the case of third person arguments 3 indicates proximate and 3' obviative referents (2.2). In intransitive forms, by contrast, the abbreviation refers to the sole argument of the verb. They are systematically included for reference.

The cells corresponding to the $1 \rightarrow 1$ and $2 \rightarrow 2$ configurations are semantically reflexive and are thus filled in grey, since in most languages they tend to be expressed by an intransitive construction ${ }^{2}$. The $3 \rightarrow 3$ cell, on the other hand, is not since the corresponding configuration is not necessarily reflexive.

Table 1: The three domains of the transitive paradigm

\begin{tabular}{l|lll}
\hline & 1 & 2 & 3 \\
\hline 1 & & $1 \rightarrow 2$ & $1 \rightarrow 3$ \\
2 & $2 \rightarrow 1$ & & $2 \rightarrow 3$ \\
3 & $3 \rightarrow 1$ & $3 \rightarrow 2$ & $3 \rightarrow 3$ \\
\hline INTR & 1 & 2 & 3 \\
\hline
\end{tabular}

This table does not represent number, clusivity and obviation, but more complex paradigms including these features will be studied below.

As will become clear in the course of this article, it is convenient to separate the transitive paradigm into three Domains (Zúñiga 2006, 47-54), represented in Table 1 by different colours. First, the LOCAL domain (in blue) comprises the forms $1 \rightarrow 2$ and $2 \rightarrow 1$, where both arguments are SAPs. Second, the NON-LOCAL domain (in red) refers to the cases where both arguments are third person. Third, the MIXED domain (in green) includes all the forms with a SAP argument and a third person $(1 \rightarrow 3,2 \rightarrow 3,3 \rightarrow 1,3 \rightarrow 2)$.

\subsection{The canonical direct/inverse system}

Given the diversity of direct/inverse systems in the world's languages, canonical typology (Corbett, 2007) seems to be a useful tool for accurately describing them by accounting for their deviation from the canon. The canonical direct/inverse system could then be defined as a type of transitive person marking system presenting three essential characteristics.

First, in such a system all person-number markers are neutral with regard to syntactic roles (S, $\mathrm{A}$ and $\mathrm{O}) .^{3}$

Second, the ambiguity which this entails (especially in mixed scenarios) is resolved by way of obligatory (and mutually exclusive) markers, called direct (in the case of $1 \rightarrow 2, \mathrm{SAP} \rightarrow 3,3 \rightarrow 3^{\prime}$ ) and inverse (in the case of $2 \rightarrow 1,3 \rightarrow \mathrm{SAP}$ and $3^{\prime} \rightarrow 3$ ), respectively. These markers do not appear on intransitive verbs. This property is generally described in terms of referential bierarchies (see section 2.3).

\footnotetext{
${ }^{2}$ The same applies, in languages with clusivity (a distinction between first person inclusive vs exclusive) to the combination of first inclusive and second person.

${ }^{3}$ See Haspelmath (2011) for a discussion of the terms S (only argument of an intransitive verb), A (more agent-like argument of a transitive verb) and $\mathrm{O}$ (more patient-like argument of a transitive verb). In terms of Bickel et al. (in press, 9)'s approach, all persons trigger agreement in all three syntactic roles.
} 
Third, inverse verb forms unlike verb forms in a passive construction, do not undergo valency changes (the verb does not become intransitive when an inverse marker is added), and the arguments keep the same syntactic properties (such as case marking and pivot accessibility) as in the direct construction.

Table 2 illustrates the canonical system, for which we have taken $1>2>3>3$ ' as the canonical person hierarchy. We can observe the perfectly symmetrical distribution of direct and inverse forms, along an axis running from the upper left side to the bottom right side of the table. Direct forms appear in orange and inverse ones in green.

Table 2: The canonical direct/inverse system

\begin{tabular}{l|llll}
\hline & 1 & 2 & 3 & $3^{\prime}$ \\
\hline 1 & & $1 \rightarrow 2$ & $1 \rightarrow 3$ & \\
2 & $2 \rightarrow 1$ & & $2 \rightarrow 3$ & \\
3 & $3 \rightarrow 1$ & $3 \rightarrow 2$ & & $3 \rightarrow 3^{\prime}$ \\
3 & & & $3 \rightarrow 3$ & \\
\hline INTR & 1 & 2 & 3 & \\
\hline
\end{tabular}

No language exactly attests the pattern in Table 2, although Rgyalrong languages (Sino-Tibetan, Sichuan, China) are among the closest to it. ${ }^{4}$

The status of the local and non-local domains varies considerably across languages, but in most languages with near-canonical systems inverse and/or direct markers can also be found in these domains.

In the local domain, all possibilities but one appear to be attested: $2 \rightarrow 1$ receives the inverse marker (as in Situ Rgyalrong), both $2 \rightarrow 1$ and $1 \rightarrow 2$ receive the inverse marker (as in Mapudungun, a language isolate of Chile), or else $1 \rightarrow 2$ and $2 \rightarrow 1$ are expressed by special forms unrelated to either the direct or the inverse ones (as in Algonquian). Another possibility is that the use of direct/inverse markers in the local domain can depend on the particular person-number combination involved (as in Kiranti languages). The one possibility not attested to the best of our knowledge is one where $1 \rightarrow 2$ would receive inverse marking whereas $2 \rightarrow 1$ would be marked as direct.

In the non-local domain, some languages with a direct/inverse system present a further contrast between proximate and obviative referents (see 2.2 for more details). In such cases, the inverse marker appears in the $3^{\prime} \rightarrow 3$ and the direct marker in the $3 \rightarrow 3^{\prime}$ configuration and the same direction markers are shared between the mixed and non-local domains.

\subsection{Proximate / obviative}

Algonquian languages have grammaticalized a distinction between two types of third person referents. These are generally designated as proximate (3) and obviative (3'). This distinction is redundantly marked on both nouns and all verb forms, including transitive and intransitive ones (see 3.1.2). In addition, the proximate / obviative status of the arguments determines the presence of direct or inverse marking on transitive verbs: in non-local scenarios, when the $\mathrm{A}$ is proximate and

${ }^{4}$ Direct/inverse systems are often illustrated with data from Algonquian languages, but they generally lack direct/inverse marking in the local domain, and are thus farther removed from the canon than Rgyalrong languages. 
the $\mathrm{O}$ is obviative, the direct form is used, whereas in the case when the $\mathrm{A}$ is obviative and the $\mathrm{O}$ is proximate, the inverse form is required. In example 1 , the verb is in the direct form, as the A is proximate and hence unmarked while the $\mathrm{O}$ is obviative (marked with the $-\mathrm{a}$ suffix), whereas in example 2 , the converse is true.

(1) mihcet nipah-êw mistanask mostosw-a many kill-3 $\rightarrow 3$ ' badger buffalo-oBv 'Badger (3) has killed many buffalo (3').'

(2) sêkih-ik nâpêw atimw-a scare-INV man dog-OBV

The dog scares the man. (Wolfart, 1973, 25)

In the mixed domain, the proximate / obviative status of the third person referent is also indicated on the verb (see Table 4).

No language outside of Algonquian displays a system in which the proximate / obviative distinction is marked on nouns, on intransitive verbs and in the mixed domain. Yet, for the purpose of typological comparison, we find it legitimate to use the terms 'proximate' and 'obviative' to describe systems which distinguish two third person referents in the non-local domain only by means of direct / inverse marking on the verb form.

Indeed, in most languages with direct/inverse systems, unlike Algonquian, the presence of direct or inverse markers on the verb is the only clue to the proximate or obviative status of a particular argument in non-local scenarios. In example 3 from Japhug Rgyalrong for instance, the absence of inverse marker on the verb indicates a direct form, which implies that the A (the maid) is proximate while the $\mathrm{O}$ (the rooster) is obviative. Inverse marking here would indicate the opposite scenario (A obviative and $\mathrm{O}$ proximate) without changing the syntactic roles.

(3) вјов пше ku kuтруарhи пш рjr-sat servant TOP ERG rooster TOP EVD-kill

'The maid killed the Rooster.' (Japhug, Aesop adaptation 'The old woman and the maid')

As is the case in Japhug, in languages with direct-inverse contrast in the non-local domain, the choice of proximate or obviative status for a particular referent (and thus the use of an inverse or a direct form) is guided by both semantics (relative animacy of the agent and patient) and pragmatics (the relative topicality or saliency of the two referents).

\subsection{Referential hierarchies}

Some authors have proposed to apply the (pre-existing) concept of referential bierarcbies in order to provide a unified account of the use of direct/inverse markers in all three domains, including the question of how the proximate or obviative status of the referents is determined.

Since DeLancey (1981a, 644), direct/inverse systems are often described in terms of the Empathy Hierarchy presented in (4): ${ }^{5}$

\footnotetext{
${ }^{5}$ For an overview of referential or prominence hierarchies, see Lockwood and Macauley (2012). These hierarchies,
} 
(4) $\mathrm{SAP}>$ third person pronoun $>$ human $>$ animate $>$ natural forces $>$ inanimate

The distribution of direct and inverse markers can then be captured by the following rule:

(5) If the patient is higher on the hierarchy than the agent, the verb receives inverse marking; conversely, if the agent is higher on the hierarchy than the patient (or if both are equal), the verb receives direct marking.

In DeLancey's view, the Empathy Hierarchy in (4) is motivated by several factors.

First, the ranking SAP $\rightarrow 3$ is due to an 'inherent natural attention flow', whereby discourse participants (first or second person) are the 'natural starting point' of most utterances. Second, the ranking within the third persons is explained by the concept of empathy, hence the name of the proposed hierarchy: 'speakers, being animate and humans, are more likely to empathize with (i.e. take the viewpoint of) human beings than animals, and of animals than inanimates.

The hierarchy in (4) is a general model which has to be adapted to each language to correctly predict the attested forms, and some variation can be observed even between closely related languages.

A detailed investigation of hierarchies in direct/inverse systems is beyond the scope of this paper (see Zúñiga 2006 for more detail). Overall, the two rankings SAP > 3 and animate > inanimate appear to be relatively robust, and can even be considered definitional of direct/inverse systems within a theoretical framework using referential hierarchies. ${ }^{6}$

Additionally, direct/inverse systems are considered by some authors as a special case of bierarchical alignment (Nichols 1992), a type distinct from accusative, ergative, active or tripartite alignment. Following Siewierska $(1998,10)$, hierarchical alignment can be defined as an alignment type where "the treatment of the $\mathrm{A}$ and $\mathrm{O}$ is dependent on their relative ranking on the referential and/or ontological hierarchies".

\section{Attested systems}

This section will present three types of hierarchical systems: near-canonical direct/inverse systems, highly non-canonical direct/inverse systems and hierarchical systems without direction (direct/inverse) markers.

\subsection{Near-canonical direct/inverse systems}

\subsubsection{Rgyalrong languages}

The direct/inverse systems of Rgyalrong languages have been described in several studies (DeLancey 1981b on Situ, Sun and Shidanluo 2002 on Tshobdun, Jacques 2010 on Japhug and ? on Zbu).

initially proposed in order to account for particular splits in case patterns (see Silverstein 1976), have also been used to explain a variety of other phenomena, including the distribution of direct and inverse markers and slot accessibility. However, it is not always possible to account for all phenomena within a given language by positing a single hierarchy, as Zúñiga 2006 has shown. In Cree for instance, no less than four distinct hierarchies are needed to explain direct/inverse marking and the allocation of person markers to the correct slot.

${ }^{6}$ Hierarchies involving $3>$ SAP may govern slot accessibility, as in the case of slots 5-7 in Cree which follow the hierarchy $1 \mathrm{PL}>1 \mathrm{INCL} / 2 \mathrm{PL}>3$ animate $>$ SAP.sG $>3$ inanimate, Zúñiga 2006, 86. This type of hierarchy has however never been described for direct/inverse morphemes. 
These languages index not only the person but also the number of the two arguments in the verbal morphology, and the resulting paradigm is more complex than the pattern shown in Table 2 .

In 6, the verb has a direct form, and the inverse is blocked, as the A is SAP while the O is third person. On the other hand, 7 illustrates the compulsory use of the inverse marker when the agent is third person and the patient SAP.

(6) ந̋́? kə əkú? tə-xsây

I ERG that AOR-hit:1sG

I hit him/her.

(7) raçór vajé? ká-lo nəjé? tə-tə-wə-xsâv yesterday 3sG one-time you AOR-2-INV-hit

(S)he hit you once yesterday.

The presence or absence of the inverse prefix in $3 \rightarrow 3$ forms (in other words, the $3^{\prime} \rightarrow 3$ vs $3 \rightarrow 3^{\prime}$ contrast) can be predicted by the following rules (Sun and Shidanluo 2002, Jacques 2010):

1. When the agent is animate and the patient inanimate, the inverse is blocked.

2. When the agent is inanimate and the patient animate, the inverse is required.

There is a strong, though not absolute, tendency for the inverse to appear when the agent is non-human animate and the patient human. When both arguments are human, there is no absolute constraint blocking or requiring the use of the inverse. $3 \rightarrow 3$ forms with inverse marking are relatively rare in comparison with direct $3 \rightarrow 3$ ' ones, and are used when the patient is markedly more topical than the agent.

Table 3 presents the non-past paradigm of a dialect of Zbu Rgyalrong. The symbols $\Sigma_{1}$ and $\Sigma_{3}$ represent different stem forms (stem 1 and stem 3, respectively). Stem 3 only occurs in a subset of direct forms, i. e. those where the patient is third person and the agent is singular $\left([123]_{\mathrm{sG}} \rightarrow 3\left({ }^{\prime}\right)\right)$ and could thus be considered as a non-canonical direct marker.

Table 3: Zbu Rgyalrong transitive paradigm (data adapted from ?)

\begin{tabular}{|c|c|c|c|c|c|c|c|c|c|c|}
\hline & $1 \mathrm{sg}$ & $1 \mathrm{DU}$ & $1 \mathrm{PL}$ & $2 \mathrm{SG}$ & $2 \mathrm{DU}$ & $2 \mathrm{PL}$ & $3 \mathrm{sg}$ & $3 \mathrm{DU}$ & $3 \mathrm{PL}$ & $3^{\prime}$ \\
\hline $1 \mathrm{sG}$ & & & & \multirow{3}{*}{$t e-\Sigma_{1}$} & \multirow{3}{*}{$t e-\Sigma_{1}-\mathrm{nd} z \partial$} & \multirow{3}{*}{ 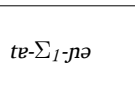 } & $\Sigma_{3-\eta}$ & $\Sigma_{3-\eta-n d z \partial}$ & इ & \\
\hline 1DU & & & & & & & \multicolumn{3}{|c|}{$\Sigma_{1-t \varphi \partial}$} & \\
\hline 1PL & & & & & & & \multicolumn{3}{|c|}{$\Sigma_{1 \text {-jə }}$} & \\
\hline $2 \mathrm{sG}$ & $t \partial-w ə-\Sigma_{1-\eta}$ & \multirow{3}{*}{$t \partial-w \partial-\Sigma_{1}-t \varphi \partial$} & \multirow{3}{*}{ tə-wว- $\Sigma_{1-\text {-jə }}$} & & & & \multicolumn{3}{|c|}{ to- $\Sigma_{3}$} & \\
\hline 2DU & tว-wว- $\Sigma_{1}-\eta-n d z ə$ & & & & & & \multicolumn{3}{|c|}{ to- $\Sigma_{1}-$-ndzə } & \\
\hline 2PL & 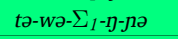 & & & & & & \multicolumn{3}{|c|}{ tə- $\Sigma_{1-л ә}$} & \\
\hline $3 \mathrm{SG}$ & $w \partial-\Sigma_{1-\eta}$ & \multirow{3}{*}{$w \partial-\Sigma_{1}-t \varphi \partial$} & \multirow{3}{*}{$w \partial-\Sigma_{1-j \partial}$} & \multirow{3}{*}{ tว-wว- $\Sigma_{1}$} & \multirow{3}{*}{ tə-wว- $\Sigma_{1}-n d z \partial$} & \multirow{3}{*}{ 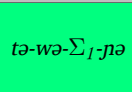 } & \multirow[b]{4}{*}{ wə- $\Sigma_{1}$} & & & $\Sigma_{3}$ \\
\hline $3 \mathrm{DU}$ & \multirow{2}{*}{$\begin{array}{l}\text { wә- } \Sigma_{1-\eta}-n d z ә \\
\text { wә- } \Sigma_{1-\eta-n ә}\end{array}$} & & & & & & & & & $\Sigma_{1}$-ndzə \\
\hline 3PL & & & & & & & & & & $\Sigma_{1-л ә}$ \\
\hline $3^{\prime}$ & & & & & & & & wə- $\Sigma_{1}$-ndzə & wว- $\Sigma_{1-л ว}$ & \\
\hline 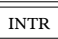 & $\Sigma_{1-\eta}$ & $\Sigma_{1-t \varphi \partial}$ & $\Sigma_{1-j \partial}$ & $t a-\Sigma_{1}$ & to- $\Sigma_{1}$-ndzo & tə- $\Sigma_{1-\text {-лә }}$ & $\overline{\Sigma_{1}}$ & $\Sigma_{1 \text {-ndzə }}$ & $\Sigma_{1 \text {-лә }}$ & \\
\hline
\end{tabular}

In this paradigm, considering only the mixed and non-local forms and leaving aside stem alternations $\left(\Sigma_{1}\right.$ vs $\left.\Sigma_{3}\right)$, there is perfect symmetry between direct and inverse forms, which are distinguished only by the presence or absence of the inverse prefix wo-. Mixed and non-local direct forms are identical to the corresponding intransitive forms except for the stem alternations. Only 
$1 \rightarrow 2$ forms are distinct from all the rest, with a synchronically opaque portmanteau $t e-1 \rightarrow 2$ prefix (if the system was perfectly symmetrical, $1 \rightarrow 2$ forms such as ${ }^{*} t-\Sigma_{1}-\eta$ would be expected).

To account for the Zbu Rgyalrong data presented above, the following hierarchy has to be posited:

(8) $1>2>3$ animate proximate $>3$ animate obviative $>3$ inanimate

Applying rule 5 to the hierarchy in (8) predicts the occurrence of the inverse in $2 \rightarrow 1,3 \rightarrow \mathrm{SAP}$ and 3 ' $\rightarrow 3$ forms, and its absence in $1 \rightarrow 2, \mathrm{SAP} \rightarrow 3$ and $3 \rightarrow 3$ '. Here proximate/obviative (or topical/nontopical) is more relevant than human/non-human as listed in the original formulation of the hierarchy in (4).

Describing Japhug Rgyalrong data in this framework would require a different hierarchy (Jacques 2012b):

(9) SAP $>3$ animate proximate $>3$ animate obviative $>3$ inanimate $>$ generic human

In Japhug, there is no inverse in $2 \rightarrow 1$ forms, while it appears with a generic human agent (disregarding the animacy of the patient).

Zbu Rgyalrong also allows us to illustrate the ways in which inverse marking can be shown to differ from passive marking. Indeed, the Zbu prefix wə-cannot be analyzed as a passive marker for several reasons.

First, it is obvious that the verb still remains transitive even in inverse forms, since especially in $2 / 3 \rightarrow 1$ sg the number markers $-n d z ə$ (dual) or $-n$ (plural) are suffixed to the first person $-\eta$ and since in all $2 \rightarrow 1$ forms both the second person tə- prefix and the first person $-\eta,-t \epsilon ə$ or $-j$ z suffixes are present. Given the fact that both the agent and the patient are indexed, one can deduce that the inverse wo- has no intransitivizing effect.

Second, the addition of the inverse prefix has no effect on case marking: third person agents still receive ergative case, as illustrated by example (10) from ?.

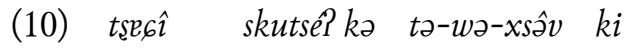

Bkrashis stone ERG AOR-INV-hit NON.VISUAL

'A stone hit bKrashis.' (The stone falls from the mountain, for example)

Third, the inverse prefix wə- is not a derivation contrary to the passive construction in this language: the semantics of inverse forms are always predictable from that of the base forms, unlike derivation prefixes in Rgyalrong languages (including passive, anticausative, antipassive etc, see Jacques 2012b) which present many irregularities.

Few direct/inverse systems are as symmetrical as the one attested in Zbu Rgyalrong, and in fact these systems present tremendous diversity across languages. Partially opaque inverse systems will be studied in more detail in 3.2.

\subsubsection{Algonquian languages}

Algonquian languages differ from Rgyalrong and all other languages with direct/inverse (apart from Kutenai) in that the proximate/obviative distinction is largely independent of direction marking on the verb. 
${ }^{7}$ It is generally considered that the second person outranks the first person $(2>1)$ in Algonquian languages, but this
refers to a distinct hierarchy related to the slot accessibility of person prefixes, not the distribution of direct and inverse forms. Concerning obviative inanimates, see a recent study by Muehlbauer (2012).

In Algonquian languages, all animate nouns are marked for proximate and obviative and all animate third person referents have a clear status as proximate or obviative in a given sentence. No such distinction is found in the case of SAP (SAPs are never obviative) nor in the case of inanimate nouns in most of these languages. Furthermore, the singular/plural distinction is neutralized in obviative forms (except in some Central Algonquian languages such as Fox and Miami-Illinois) or else there is no contrast between proximate and obviative in the plural (as in Blackfoot). In a single sentence, at most one argument can be proximate, but it is also possible to find sentences with only obviative arguments.

Table 4 (adapted from Wolfart, 1973) illustrates an example of a transitive animate paradigm (the verb wâpam- "see") and an intransitive animate one with pimipahtâ- "run". The direct markers are $-\hat{a}-$ or $-\hat{e}-$ and the inverse marker is $-i k(o)$. Please note that the proximate/obviative distinction is also marked on intransitive verbs.

Table 4: Plains Cree present paradigms. TA wâpam- "see” and IA pimipahtâ-“run” (Wolfart, 1973)

\begin{tabular}{|c|c|c|c|c|c|c|c|c|}
\hline A & $1 \mathrm{sG}$ & 1PI & $1 \mathrm{PE}$ & $2 \mathrm{sg}$ & $2 \mathrm{PL}$ & $3 \mathrm{sg}$ & $3 \mathrm{PL}$ & $3^{\prime}$ \\
\hline 1SG & & & & kiwâpamitin & kiwâpamitinâwâw & niwâpamâw & niwâpamâwak & niwâpamimâwa \\
\hline 1PI & & & & & & kiwâpamânaw & kiwâpamânawak & kiwâpamimânawa \\
\hline $1 \mathrm{PE}$ & & & & \multicolumn{2}{|c|}{ kiwâpamitinân } & niwâpamânân & niwâpamânânak & niwâpamimânâna \\
\hline $2 \mathrm{sg}$ & kiwâpamin & & \multirow{2}{*}{ kiwâpaminân } & & & kiwâpamâw & kiwâpamâwak & kiwâpamimâwa \\
\hline $2 \mathrm{PL}$ & kiwâpaminâwâw & & & & & kiwâpamâwâw & kiwâpamâwâwak & kiwâpamimâwâwa \\
\hline $\begin{array}{l}3 \mathrm{sG} \\
3 \mathrm{PL}\end{array}$ & $\begin{array}{l}\text { niwâpamik } \\
\text { niwâpamikwak }\end{array}$ & $\begin{array}{l}\text { kiwâpamikonaw } \\
\text { kiwâpamikonawak }\end{array}$ & $\begin{array}{l}\text { niwâpamikonân } \\
\text { niwâpamikonânak }\end{array}$ & $\begin{array}{l}\text { kiwâpamik } \\
\text { kiwâpamikwak }\end{array}$ & $\begin{array}{l}\text { kiwâpamikowâw } \\
\text { kiwâpamikowâwak }\end{array}$ & & & $\begin{array}{l}\text { wâpam(im)êw } \\
\text { wâpam(im)êwak }\end{array}$ \\
\hline $3^{\prime}$ & niwâpamikoyiwa & kiwâpamikonawa & niwâpamikonâna & kiwâpamikoyiwa & kiwâpamikowâwa & wâpamik & wâpamikwak & $\begin{array}{l}\text { wâpamêyiwa } \\
\text { wâpamikoyiwa }\end{array}$ \\
\hline INTR & nipimipahtân & kipimipahtâ(nâ)naw & nipimipahtânân & kipimipahtân & kipimipahtânâwâw & pimipahtâw & pimipahtâwak & pimipahtâyiwa \\
\hline
\end{tabular}

On transitive verbs, the proximate/obviative appears in the mixed domain: there are different forms for SAP $\leftrightarrow 3$ PROX and SAP $\leftrightarrow 3$ OBV. In the non-local domain, three configurations with direct and inverse marking are observed: $3 \rightarrow 3^{\prime}, 3^{\prime} \rightarrow 3$ and $3^{\prime} \rightarrow 3^{\prime}$. While the first two are attested in other languages with direct/inverse systems, the third one is only found in Algonquian. Here, $3^{\prime} \rightarrow 3^{\prime}$ (as in the form wâpam-êyiwa 'he $\mathrm{e}_{o b v}$ sees him $_{o b v}$ ') is the so-called further obviative form, which is often abbreviated as 3' $\rightarrow 3$ ". Example 11 illustrates this form with the verb nipah- 'to kill'.

(11) pêyak piko nipah-êyiwa o-mis-a wâposw-a one just kill-3' $\rightarrow$ 3' 3 Poss-older $_{s}$ ister-OBV rabbit-OBV 'His sister had killed but one rabbit.' (Wolfart, 1996, p. 401)

Such a form illustrates the fact that a given sentence can have any number of obviative arguments. Thus, a configuration with two obviative arguments does not imply reflexivization.

The morphosyntactic marking of the proximate/obviative distinction presents some noteworthy differences with other languages with direct/inverse such as Rgyalrong.

First, in Algonquian, we observe a tripartite distinction between proximate animate, obviative animate and inanimate referents. Indeed, the empathy hierarchy for Cree would be the following: ${ }^{7}$

(12) SAP > animate proximate $>$ animate obviative $>$ inanimate 
Second, the proximate/obviative distinction in Rgyalrong is only present in $3 \rightarrow 3^{\prime}$ and $3{ }^{\prime} \rightarrow 3$ verb forms, while in Algonquian it is also redundantly marked on nouns, intransitive verbs and transitive mixed forms.

Third, in Algonquian languages, the possessee of a SAP possessor can be either proximate or obviative, but the possessee of a third person proximate referent must be obviative. Thus, in example 13, where the possessee ('John's dog') is the agent and the possessor ('John') is the patient, the inverse suffix $-i k$ is required, since the former ('John's dog') is automatically obviative.

Cân o-têm-a kî̀-mâkwam-ik

John 3sG.POss-dog-OBV PST-bite-INV

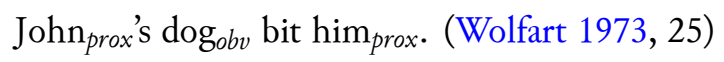

Although a similar constraint has been described in other language families such as Mayan (see Aissen 1997), no such phenomenon is attested in other languages with direct/inverse in nonlocal forms, such as Rgyalrong languages, for instance (see Jacques 2010, 141-2), and is thus not a universal property of proximate/obviative marking.

This comparison of Rgyalrong and Algonquian shows that while the proximate/obviative distinction may appear to be a subset of the direct/inverse in non-local forms, the two phenomena are fundamentally different and only intersect in the $3 \rightarrow 3^{\prime}$ and $3^{\prime} \rightarrow 3$ configurations. Nearly all languages whose direct/inverse system includes the non-local domain behave like Rgyalrong languages. The only exceptions we are aware of are Algonquian and Kutenai, but even the latter has a much simpler system than Algonquian. This also confirms the fact that the Algonquian direct/inverse system, while undeniably the first to have been properly described, is by no means representative.

\subsection{Highly non-canonical direct/inverse systems}

Highly non-canonical inverse systems comprise two main types: systems with the direct/inverse contrast present in the local or non-local domains but not in the mixed domain, or systems where the direct or inverse markers are polyfunctional. For lack of space, we will only illustrate the second case, using data from Khaling, a Kiranti language of Nepal (Jacques et al. 2012). ${ }^{8}$

As can be seen in Table 5, Khaling has a prefix 2i- which appears in the second person forms of intransitive verbs as well as in the following transitive configurations: $2 \rightarrow 1,3 \rightarrow 1,3 \rightarrow 2$ and $2 \rightarrow 3$. Additionally, it appears in $1 \mathrm{DU} / \mathrm{PL} \rightarrow 2$ forms which are not shown in that table. Khaling has no contrast between 3 and 3'.

Table 5: Khaling verbal system (singular forms only)

\begin{tabular}{l|lll}
\hline & 1 & 2 & 3 \\
\hline 1 & & $\Sigma-n \varepsilon$ & $\Sigma-u$ \\
2 & $2 i-\sum-\eta \Lambda \Lambda$ & & $2 i-\sum-\boldsymbol{u}$ \\
3 & $2 i-\sum-\eta \Lambda \Lambda$ & $2 i-\Sigma$ & $\Sigma-\boldsymbol{u}$ \\
\hline INTR & $\sum-\eta \Lambda \Lambda$ & $2 i-\Sigma$ & $\Sigma$ \\
\hline
\end{tabular}

${ }^{8}$ The first case is represented by languages with proximate/obviative marking only in the non-local domain (Kutenai, Navajo) and languages with inverse only in local forms such as Nez Percé. 
The prefix 2i-can be described as appearing in all forms involving the second person (except $1 \mathrm{sG} \rightarrow 2$ ) and in all inverse forms. It is thus a conflation of a second person marker and an inverse marker, which has little synchronic functional motivation and cannot be described in terms of a hierarchy, even though a historical explanation seems possible (see section 5.2). We could gloss the Khaling prefix as $2 /$ INV, but it would be misleading to refer to it as an inverse marker.

Prefixes with a distribution nearly identical to that of Khaling $2 i-$ are found in related languages such as Dumi, Trung and Rawang (van Driem 1993).

\subsection{Hierarchical agreement without direction marking}

Hierarchical systems without direct/inverse marking can be illustrated with data from Icari Dargwa (Nakh-Daghestanian, Sumbatova and Mutalov 2003).

This language illustrates the fact that the access to inflectional slots may be described in terms of an indexability hierarchy. There are two clitics (=di ' $2 \mathrm{~s}$ ' and $=d a$ ' $1,2 \mathrm{p}$ ') which mark person in several TAM forms, such as the preterite. Second person arguments are always indexed on the verb irrespective of their grammatical role (S, A, or O). On the other hand, 1st person arguments are indexed only if there is no 2 nd person involved (see 14 vs 15 )

(14) $\quad d u-l \quad u \quad u c-i b=d i \quad 1>2$

1SG-ERG $2 \mathrm{SG}(\mathrm{ABS})$ catch.M.PFV-PRET $=2 \mathrm{SG}$

I caught you.

(15) $\quad$ du-l $\quad$ Murad $u c-i b=d a$

1SG-ERG M. catch.M.PFV-PRET=1sG

I caught Murad.

Finally, when there are no SAP arguments, none of these clitics is used. In other words, person indexability is only determined by the hierarchy $2>1>3$, not by grammatical roles (see Table 6 with the verb uc- "to catch" in the preterit form $-i b)$.

Table 6: Icari Dargwa person markers in the preterite

\begin{tabular}{cccc}
\hline & 1 & 2 & 3 \\
\hline 1 & & $u c-i b=d i$ & $u c-i b=d a$ \\
2 & $u c-i b=d i$ & & $u c-i b=d i$ \\
3 & $u c-i b=d a$ & $u c-i b=d i$ & $u c-i b$ \\
\hline
\end{tabular}

The paradigm in Table 6 is the prime example of a hierarchical system without a direction marker.

However, this simple picture looks different when TAM categories derived from the thematic stem are taken into account (Sumbatova and Mutalov, 2003, 81-82, 99).

The choice of the thematic vowel follows the hierarchy SAP > non-SAP. Thus, $-i$ - shows that the Agent is higher on the hierarchy than the Patient, - $u$ - that this is not the case, i.e. $-i$ - is used if the AgEnt is SAP and the patient isn't, and $-u$ - in all other cases (including intransitive forms, 
except with 3 person subjects where -ar-/-an- is used instead). Person markers in the thematic TAM categories cross-reference only SAP: we have $-d$ ' 1 st person ( $\mathrm{sG} / \mathrm{PL})$ ' and $-\bar{t} /-\bar{t} a$ ' 2 nd person ( $\mathrm{sG} / \mathrm{PL}$ )', the 3rd person being unmarked (cf. Table 7).

Table 7: Icari Dargwa Potential Present verb paradigm

\begin{tabular}{|c|c|c|c|c|}
\hline A & 1 & $2 \mathrm{~s}$ & $2 p$ & 3 \\
\hline 1 & & urc-u- $\bar{t}$ & $u r c-u-\bar{t}-a$ & $u r c-i-d$ \\
\hline $2 s$ & $u r c-u-\bar{t}$ & & & $u r c-i-\bar{t}$ \\
\hline $2 p$ & $u r c-u-\bar{t}-a$ & & & urc-i- $\bar{t}-a$ \\
\hline 3 & $u r c-u-d$ & $u r c-u-\bar{t}$ & $u r c-u-\bar{t}-a$ & urc-u \\
\hline
\end{tabular}

Although pure hierarchical systems without any direct or inverse marker are well attested, ${ }^{9}$ it is possible that many languages with hierarchical alignment appearing to lack direction markers may reveal restricted direct or inverse marking in some areas of their grammar, like Icari Dargwa. In particular, Tangut (Sino-Tibetan; extinct) is generally presented as having a verbal agreement system very close to that of Dargi in Table 6 (the only significant difference being that in Tangut in local forms the verb agrees with the patient, thus $2 \rightarrow 1$ receives the first person marker instead of the second person marker as in Dargi, cf Kepping 1981). However, it has more recently been shown that Tangut consistently distinguishes SAP.sG $\rightarrow 3$ and $3 \rightarrow$ SAP.sg by stem alternation in the direct forms (Jacques 2009).

\section{Typological perspectives}

An important question concerning direct/inverse systems is to what extent this typological feature is correlated with other features. Klaiman $(1992,1991,165-169)$ has proposed a correlation with head-markedness and configurationality, which was indeed observed in most of the languages in her sample.

More than twenty years after Klaiman's work, it seems unlikely that direct/inverse could be correlated with any other feature (or set of features) in particular. Table 8 presents data from Zbu (?), Cree (Wolfart 1973), Sahaptin (Rude 1997, Zúñiga 2006), Navajo (Willie 2000), Dargwa (Sumbatova and Mutalov 2003), Movima (Haude 2009) and Mapudungun (Zúñiga 2006).

This table indicates whether the inverse in these languages appears in the local, non-local or mixed domains, as well as the presence or absence of other typologically relevant features such as head-markedness, discontinuous constituents, case marking, polypersonal marking on the verb, incorporation, and strong noun-verb distinction.

These data show that languages with direct/inverse systems, though mainly head-marking and polysynthetic (i.e. having noun incorporation and polypersonal marking), need not be so. It is important to note that non-configurationality, if understood as allowing discontinuous constituents, is likewise rare among such languages.

${ }^{9}$ The Tupi-Guarani family provides many examples of such systems (see for instance Rose 2009). 
Table 8: Direct/inverse and other typological features

\begin{tabular}{|c|c|c|c|c|c|c|c|c|c|c|}
\hline Family & Language & $\begin{array}{l}\text { Head- } \\
\text { marking }\end{array}$ & $\begin{array}{l}\text { Discontinous } \\
\text { constituents }\end{array}$ & Non-local & Mixed & Local & Case & Noun / Verb & Incorporation & $\begin{array}{l}\text { Polypersonal } \\
\text { marking on the verb }\end{array}$ \\
\hline Rgyalrongic (ST) & Zbu & $\mathrm{x}$ & & $\mathrm{x}$ & $\mathrm{x}$ & $\mathrm{x}$ & ergative & strong & $\mathrm{x}$ & $\mathrm{x}$ \\
\hline Algonquian (Algic) & Cree & $\mathrm{x}$ & $\mathrm{x}$ & & $\mathrm{x}$ & $\mathrm{x}$ & obviative & strong & $\mathrm{x}$ & $\mathrm{x}$ \\
\hline Sahaptian & Sahaptin & $\mathrm{x}$ & $\mathrm{x}$ & $\mathrm{x}$ & & $\mathrm{x}$ & tripartite & strong & & \\
\hline Athabaskan & Navajo & $\mathrm{x}$ & & $\mathrm{x}$ & & & & strong & & $\mathrm{x}$ \\
\hline Nakh-Daghestanian & Dargwa & & & $\mathrm{x}$ & $\mathrm{x}$ & $\mathrm{x}$ & ergative & strong & & \\
\hline Isolate & Movima & & & $\mathrm{x}$ & $\mathrm{x}$ & $\mathrm{x}$ & & omnipredicative & $\mathrm{x}$ & \\
\hline Isolate & Mapudungun & $\mathrm{x}$ & & $\mathrm{x}$ & $\mathrm{x}$ & $\mathrm{x}$ & & strong & $\mathrm{x}$ & $\mathrm{x}$ \\
\hline
\end{tabular}

Given the limited number of languages with direct/inverse systems, it may prove difficult to ascertain whether the presence of such a system in a given language could be correlated with the presence or absence of other features. Indeed, even if we surveyed all such languages, the resulting sample would still be too limited to provide any statistically significant results, especially if all languages of a particular subgroup (Algonquian or Rgyalrong, for instance) are counted as one token.

\subsection{Extension of the concept of direct/inverse}

As defined in section 2 and even taking into account highly non-canonical inverse systems, direct/inverse systems represent a very restricted phenomenon only attested in a minority of languages. Givón (1994) has proposed to extend this term to a broader set of phenomena.

Givón $(1994,9)$ defines the inverse as a type of de-transitive voice where 'the patient is more topical than the agent but the agent retains considerable topicality', unlike the passive where the agent is extremely non-topical (demoted or suppressed). He strictly distinguishes between pragmatic inverse (the optional use of the inverse to indicate that the agent is more topical than the patient) and semantic inverse (the obligatory use of the inverse conditioned by the relative ranking of the agent and patient on a particular referential hierarchy).

Under this view, inverse constructions are not limited to hierarchical systems, but the concept can be extended to describe topic fronting, a phenomenon he designates as word-order inverse. This extension of the concept of direct/inverse, while it has some merits in terms of cross-linguistic comparison, may run into difficulties when analysing the syntax of languages with a near-canonical direct/inverse system, as those languages also have topic fronting and right extraposition, and topic fronting of the patient is not always correlated with the use of the inverse.

Regardless of terminological preferences, Givonian text counts (in particular of referential distance and topic persistence, Givón 1994, 10) have provided an easily reproductible and insightful basis on which to build a cross-linguistic study of direct/inverse systems. It has been successfully applied to various languages with direct/inverse, such as Kutenai (Dryer 1994) and Japhug Rgyalrong (Jacques 2010).

\section{Diachronic perspective}

Recent work such as Cristofaro (2013) has called into question the functional validity of referential hierarchies as an explanatory tool to account for the existence of direct/inverse systems. Instead, 
it suggests that the structure of direct/inverse systems might be better explained by taking into account the diachronic origin of these markers.

In this section, we provide a panchronic overview of direct and inverse markers: their origins from and their development into other markers. Still, this type of research is fraught with difficulties for two main reasons. First, most languages with direct/inverse marking (such as Movima, Kutenai, Mapudungun) are isolates and thus cannot be easily studied in a diachronic perspective. Second, since there are no languages with a near-canonical inverse with a written tradition predating the seventeenth century (when Wampanoag was first put to writing by John Eliot), the data presented here are reconstructions obtained by using the comparative method, and may be subject to revision in the future.

\subsection{Origins of inverse marking}

The best attested origin of inverse markers is from an earlier cislocative. Two additional sources (an earlier passive or a third person marker) have been identified, but examples are fewer and more difficult to interpret.

\subsubsection{Cislocative}

The term 'cislocative' is used to refer to markers expressing a motion towards the speaker, both directional ('verb hither') and associated motion ('come to verb') ones. ${ }^{10}$

The inverse marker in Nez Percé (Sahaptian) used in local scenarios with second person acting on first person has grammaticalized from an earlier cislocative marker, reconstructed for ProtoSahaptian as ${ }^{*}$-im (Rude, 1997, 122).

(16) béexn-e see-PST

I saw you.

(17) bexn-im-e

see-CIs-PST

You saw me.

Interestingly, this marker has also grammaticalized into the ergative case suffix which appears on the non-SAP agent in mixed scenarios in cases where one would expect inverse marking on the verb (Rude, 1997, 121-2).

(18) bi-béxn-e báama-nm

3s/A $\rightarrow$ SAP-see-PST man-ERG

The man saw me/you. (Nez Percé)

This grammaticalization path is also attested in Sino-Tibetan. DeLancey $(2013,13-14)$ reports that in several Kuki-Chin languages a verb meaning 'to come' (reconstructed for Proto-Kuki-Chin as *hun by VanBik 2009, 191) has grammaticalized to a varying degree in different languages into a

${ }^{10}$ On the grammaticalization of associated motion markers from motion verbs, see Jacques (2013). 
cislocative 'hither' prefix on motion verbs. Interestingly, in some Northern and Central languages, it has developed the additional function of optionally marking some transitive or ditransitive configurations involving a 1st person patient as in Bawm (example 19) or 1st or 2nd person patient, as in Sizang (example 20).

(19) ka pâ nib bâi hawng ka pêk 1sG father ERG cup CIS 1sG give

My father gives me the cup. (Reichle 1981, 147-149, cited in DeLancey 2013, 14)

(20) naymá: $k-o \eta \quad n e ́: t \hat{u}: b \hat{\imath}:$

you $15 \mathrm{sG}-\mathrm{CIs}$ eat will FIN

I will eat you. (Stern 1984, 48, cited in DeLancey 2013, 13)

Even if we are not dealing with a fully grammaticalized direct/inverse system, the process towards its shaping is well under way.

Similar developments which have not (as yet) reached the same target, are also attested in the unrelated languages Shasta (Shastan, extinct), the Northern Iroquoian languages Cayuga, Tuscarora and Mohawk (Mithun, 1996), but also in Modern Japanese (Shibatani, 2003, 2006; Koga and Ohori, 2008) and Kabardian (Kumakhov and Vamling, 2006, 68ff). In all of these languages a cislocative has evolved, or is currently evolving, into a first person patient or a portmanteau $2 \rightarrow 1$ marker.

As for the grammaticalization path involved, it need not have been the same in all of the languages concerned. Based on data from Japanese (Japonic) and Circassian (NW Caucasian) and the following tentative grammaticalization pathway could be proposed:

$$
\text { (21) COME } \rightarrow \text { CISLOCATIVE associated motion directional } \rightarrow \text { ('sudden action')? } \rightarrow \text { INVERSE }
$$

Indeed, apart from their incipient use as a marker of grammatical relations in mixed scenarios, cislocative markers in these two languages have independently developed a secondary meaning of 'sudden action', a semantic extension not attested in the other languages of the sample. Therefore, the pathway proposed in (21) may not be applicable to other languages where the inverse originated from an earlier cislocative marker and so further research is needed.

\subsubsection{Passive}

A second grammaticalization pathway from passive to inverse has been proposed by several authors, the most prominent of whom is Givón (1994).

This pathway could perhaps be attested in the case of Algonquian. At present, there is no consensus on the origin of the inverse marker (used in the independent order) which has been reconstructed for Proto-Algonquian as *-ekw (Bloomfield, 1946, 98, Goddard, 1979, 89).

Goddard (1974) pointed out a possible Wiyot cognate, but the data is too fragmentary to draw any firm conclusions. Yurok, the only other relative of Algonquian, has a passive suffix -oy (Robins 1958, 56-8) which presents affinities with inverse marking: it is required in some $3 \rightarrow$ SAP forms and blocked in $\mathrm{SAP} \rightarrow 3$. However, this passive suffix is not relatable to Algonquian *-ekw by known phonetic laws (A. Garrett, p.c.). 
Still, McLean (2001) has proposed that the Algonquian inverse suffix *-ekw originated from a passive marker whose function was similar to the suffix -oy in Yurok. There is some evidence for this in modern languages such as Cree and Ojibwe which still have a passive construction distinct from the inverse one but sharing with it the *-ekw element. In Ojibwe (Valentine 2001, 689), for instance, the passive SAP form is marked by -igoo, a compound suffix which could be tentatively analyzed as resulting from the fusion of the inverse $-i g w$ with the intransitive animate verb derivational suffix - aa.

\subsubsection{Third person}

In still other languages, we observe a formal similarity between some inverse or direct markers and various types of third person markers including agent, patient or possessive affixes.

The clearest case is the inverse prefix found in Sino-Tibetan (Rgyalrongic and Kiranti) languages. As first noticed by DeLancey (1981b), the Situ Rgyalrong third person possessive prefix wo- is formally identical to the inverse marker. This is also true of other Rgyalrong languages and of some Kiranti languages that have an inverse marker, such as Bantawa (see Table 9, data from ? and Doornenbal 2009).

Table 9: Comparison of inverse and third person prefixes in Rgyalrong and Kiranti

\begin{tabular}{llll}
\hline & language & inverse marker & third person possessive \\
\hline \multirow{4}{*}{ Rgyalrong } & Situ & wə- & wə- \\
& Tshobdun & $o-$ & $o-$ \\
& Zbu & $w \partial-$ & $w \supset-$ \\
\hline Kiranti & Bantawa & $\dot{i-}<{ }^{*} \mathrm{u}-$ & $\dot{i-}<{ }^{*} \mathrm{u}-$ \\
\hline
\end{tabular}

The similarity between the two sets of prefixes is striking, and suggests a grammaticalization from a third person marker into an inverse marker. While the exact pathway remains unclear and thus requires further investigation, it is possible that non-finite verb forms carrying a third person possessive prefix were reanalyzed as finite ones. In the case of Sino-Tibetan languages, this scenario probably occurred in the ancestor of both Rgyalrongic and Kiranti languages (see Jacques 2012a and DeLancey 2011).

\subsection{Stability of direct/inverse systems}

Direct/inverse marking appears to be quite stable in at least one family: Algonquian. The system can be reconstructed back to Proto-Algonquian (Goddard 1979, 89) and has been preserved with little modification in all daughter languages.

However, in Sino-Tibetan, the only other large family where direct/inverse systems are attested, near-canonical direct/inverse systems are only present in the Rgyalrong languages described in section 2.1. Other Sino-Tibetan languages show highly non-canonical or even completely opaque inverse systems (cf. Kiranti languages described in section 3.2).

In this connection, Lavrung (Huang 2007, 69-70, Lai 2013) shows an interesting evolution which might help us understand how such opaque systems develop. A comparison of the data in 
Table 10 with the Zbu Rgyalrong paradigm in 3 shows that the 2 - prefix neatly corresponds to the inverse $w \partial-$ in Z Zu and indeed the system we have in Lavrung, though slightly less canonical than that of Zbu, is still what we would call a near-canonical inverse system.

Table 10: Lavrung verbal paradigm (singular and plural forms)

\begin{tabular}{|c|c|c|c|c|c|}
\hline & $1 \mathrm{sg}$ & $1 \mathrm{pl}$ & $2 \mathrm{sg}$ & $2 \mathrm{pl}$ & 3 \\
\hline $\begin{array}{l}1 \mathrm{sg} \\
1 \mathrm{pl}\end{array}$ & & & $\sum-n$ & $\Sigma_{-n}$ & $\begin{array}{l}\Sigma-a \eta \\
\Sigma-j\end{array}$ \\
\hline $\begin{array}{l}2 \mathrm{sg} \\
2 \mathrm{pl}\end{array}$ & $\partial-\Sigma-a \eta$ & $\partial-\Sigma-j$ & & & $\begin{array}{l}\Sigma-n \\
\Sigma-n\end{array}$ \\
\hline 3 & & & $\partial-\sum-n$ & a- $\Sigma-n$ & $\partial-\Sigma$ \\
\hline INTR & $\Sigma-a \eta$ & $\Sigma_{-j}$ & $\sum-n$ & $\Sigma_{-n}$ & $\Sigma$ \\
\hline
\end{tabular}

Lavrung appears to differ from Zbu mainly in having lost direct inverse contrast in non-local forms $\left(3 \rightarrow 3^{\prime}\right.$ and $\left.3^{\prime} \rightarrow 3\right)$ to the benefit of the inverse form. This evolution appears somewhat contrary to a priori expectation, given that inverse could be construed as being the marked form, and the direct the unmarked form. Lavrung thus represents a first step in the direction of an opaque (direct/inverse) system. The prefix 2 - cannot be analyzed synchronically as a third person agent marker, since it occurs in $2 \rightarrow 1$ forms, but it is not a canonical inverse marker anymore either, since it also occurs in all $3 \rightarrow 3$ forms.

There is no consensus as to how exactly the opaque systems observed in Kiranti came into existence, but a possibility is that they originated from a direct/inverse system similar to that observed in Rgyalrong languages, and then underwent a series of changes which thorougly reshaped the system starting with a generalization of the inverse marker in non-local scenarios as in the case of Lavrung. This in turn increased morphological opacity up to a point where many individual morphemes (like Khaling ?i-) ceased to have a synchronically straightforward morphosyntactic function.

\section{Conclusion}

Direct/inverse systems in the narrow sense are a rare type of agreement system, observed mainly in languages of the Americas and the greater Himalayan region. Nevertheless, their theoretical importance cannot be overestimated. Indeed, they have served as one of the models for the development of the concept of referential bierarchies and the idea of setting bierarcbical alignment as a category distinct from accusative, ergative, active or tripartite alignment.

Direct/inverse systems are attested in extremely endangered languages, and much work is still needed for a detailed and meticulous description of such systems. In particular the precise conditions for the use of direct and inverse forms in the non-local domain is a topic of research which cannot be based on elicitation, but requires extensive work on authentic oral corpora. A finer-grained approach to morphosyntactic diversity is necessary, and recent research on Rgyalrongic languages for instance has revealed subtle but important differences in the use of the inverse across closely related language varieties. 


\section{References}

Aissen, Judith. 1997. On the Syntax of Obviation. Language 73, 705-750. 73.4:705-750.

Bickel, Balthasar, Giorgio Iemmolo, Taras Zakharko, and Alena Witzlack-Makarevich. in press. Patterns of alignment in verb agreement. In Languages across boundaries: studies in memory of Anna Siewierska, ed. Dik Bakker and Martin Haspelmath. Berlin: de Gruyter Mouton.

Bloomfield, Leonard. 1946. Algonquian. In Linguistic structures of native America, ed. Harry Hoijer and Cornelius Osgood, volume 6 of Viking Fund Publications in Anthropology, 85-129. New York: Wenner-Gren Foundation.

Corbett, Greville G. 2007. Canonical typology, suppletion and possible words. Language 83.1:8-42.

Cristofaro, Sonia. 2013. The referential hierarchy: reviewing the evidence in diachronic perspective. In Languages Across Boundaries, ed. Dik Bakker and Martin Haspelmath, 69-94. Berlin, New York: Mouton de Gruyter.

DeLancey, Scott. 1981a. An interpretation of split ergativity. Language 57.3:626-57.

DeLancey, Scott. 1981b. The category of direction in Tibeto-Burman. Linguistics of the TibetoBurman Area 6.1:83-101.

DeLancey, Scott. 2011. Notes on verb agreement prefixes in Tibeto-Burman. Himalayan Linguistics Journal 10.1:1-29.

DeLancey, Scott. 2013. Argument Indexation (Verb Agreement) in Kuki-Chin. URL http://www.academia.edu/4155394/Argument_Indexation_Verb_Agreement_in_ Kuki-Chin, paper presented at the Workshop on Issues in Kuki-Chin Linguistics at the 46th International Conference on Sino-Tibetan Languages and Linguistics, Dartmouth College, August 7, 2013.

Doornenbal, Marius. 2009. A Grammar of Bantawa: Grammar, paradigm tables, glossary and texts of a Rai language of Eastern Nepal. Doctoral Dissertation, Leiden University.

van Driem, George. 1993. The Proto-Tibeto-Burman verbal agreement system. Bulletin of the School of Oriental and African Studies 61.2:292-334.

Dryer, Matthew. 1994. The Discourse Function of the Kutenai Inverse. In Voice and Inversion, ed. Talmy Givon, 65-99. Amsterdam: Benjamins.

Givón, Talmy. 1994. The pragmatics of de-transitive voice: Functional and typological aspects of inversion. In Voice and inversion. Amsterdam: Benjamins.

Goddard, Ives. 1974. Remarks on the Algonquian Independent Indicative. International Journal of American Linguistics 40.4:317-327.

Goddard, Ives. 1979. Comparative Algonquian. In The languages of Native America, ed. Lyle Campbell and Marianne Mithun, 70-132. Austin: University of Texas Press. 
Haspelmath, Martin. 2011. On S, A, P, T, and R as comparative concepts for alignment typology. Linguistic Typology 15.3:535-567.

Haude, Katharina. 2009. Hierarchical alignment in Movima. International Journal of American Linguistics 75.4:513-532.

Huang, Bufan. 2007. Lawurongyu yanjiu 拉塢戎語研究 (Study on the Lavrung language). Beijing: Minzu chubanshe.

Jacques, Guillaume. 2009. The Origin of Vowel Alternations in the Tangut Verb. Language and Linguistics 10.1:17-28.

Jacques, Guillaume. 2010. The Inverse in Japhug Rgyalrong. Language and Linguistics 11.1:127-157.

Jacques, Guillaume. 2012a. Agreement morphology: the case of Rgyalrongic and Kiranti. Language and Linguistics 13.1:83-116.

Jacques, Guillaume. 2012b. Argument demotion in Japhug Rgyalrong. In Ergativity, Valency and Voice, ed. Katharina Haude and Gilles Authier, 199-226. Berlin: Mouton De Gruyter.

Jacques, Guillaume. 2013. Harmonization and disharmonization of affix ordering and basic word order. Linguistic Typology 17.2:187-217.

Jacques, Guillaume, Aimée Lahaussois, Boyd Michailovsky, and Dhan Bahadur Rai. 2012. An overview of Khaling verbal morphology. Language and linguistics 13.6:1095-1170.

Kepping, Ksenija Borisovna. 1981. Agreement in the Tangut verb. Linguistics of the Tibeto-Burman area 6.1:39-48.

Klaiman, M.H. 1991. Grammatical voice. Cambridge: Cambridge University Press.

Klaiman, M.H. 1992. Inverse languages. Lingua 88.3/4:227-261.

Koga, Hiroaki, and Toshio Ohori. 2008. Reintroducing inverse constructions in Japanese. In Investigations of the Syntax-Semantics-Pragmatics Interface, ed. Robert D. Van Valin Jr. Amsterdam: John Benjamins.

Kumakhov, Mukhadin, and Karina Vamling. 2006. Ėrgativnost' v čerkesskix jazykax. Malmo University.

Lai, Yunfan. 2013. La morphologie affixale du lavrung wobzi. Master's thesis, Université Paris III.

Lockwood, Hunter T., and Monica Macauley. 2012. Prominence hierarchies. Language and Linguistics Compass 6.7:431-446.

McLean, Lisa M. 2001. A passive to inverse reanalysis in Cree. Master's thesis, Univeristy of Manitoba at Winipeg.

Mithun, Marianne. 1996. New directions in referentiality. In Studies in Anaphora, ed. Barbara Fox, volume 33 of Typological Studies in Language, 413-435. Amsterdam: John Benjamins. 
Muehlbauer, Jeffrey. 2012. The Relation of Switch-Reference, Animacy, and Obviation in Plains Cree. International Journal of American Linguistics 78.2:203-238.

Nichols, Johanna. 1992. Linguistic Diversity in Space and Time. Chicago: University of Chicago Press.

Reichle, Verena. 1981. Bawm language and lore. Peter Lang.

Robins, R. H. 1958. The Yurok Language. Berkeley: University of California Press.

Rose, Françoise. 2009. A hierarchical indexation system: the example of Emerillon (Teko). In New Challenges in Typology, ed. Patience Epps and Alexander Arkhipov, 63-83. Berlin: Mouton de Gruyter.

Rude, Noel. 1997. On the history of nominal case in Sahaptian. International Journal of American Linguistics 63:113-43.

Shibatani, Masayoshi. 2003. Directional verbs in Japanese. In Motion, Direction and Location in Languages: In Honor of Zygmunt Frajzyngier, ed. Erin Shay and Uwe Seibert, 259-286. John Benjamins.

Shibatani, Masayoshi. 2006. On the conceptual framework for voice phenomena. Linguistics 44:217-269.

Siewierska, Anna. 1998. On nominal and verbal person marking. Linguistic Typology 2:1-56.

Silverstein, Michael. 1976. Hierarchy of Features and Ergativity. In Grammatical Categories in Australian Languages, ed. Robert M.W. Dixon. Canberra: Australian Institute of Aboriginal Studies.

Stern, Theodore. 1984. Sizang (Siyin) Chin texts. Linguistics of the Tibeto-Burman Area 8:43-58.

Sumbatova, Nina R., and Rasul O. Mutalov. 2003. A grammar of Icari Dargwa. München: Lincom Europa.

Sun, Jackson T.-S., and Shidanluo. 2002. Caodeng Jiarongyu yu rentong dengdi xiangguan de yufa xianxiang 草登嘉戎語與「認同等第」相關的語法現象 (Empathy Hierarchy in Caodeng rGyalrong grammar). Language and Linguistics 3.1:79-99.

Valentine, J. Randolph. 2001. Nishnaabemwin Reference Grammar. Toronto: University of Toronto Press.

VanBik, Kenneth. 2009. Proto-Kuki-Chin, volume 8 of STEDT Monograph Series. university of California.

Willie, Mary-Ann. 2000. The Inverse Voice and Possessive yi/bi. International Journal of American Linguistics 66.3:360-382.

Wolfart, H. Christoph. 1973. Plains Cree: A Grammatical Study. Transactions of the American Philosophical Society 63.5:1-90. 
579 Wolfart, H. Christoph. 1996. Sketch of Cree, an Algonquian Language. In Languages, ed. Ives 580 Goddard and William C. Sturtevant, volume 17 of Handbook of North American Indians, 390-439. 581 Washington D.C.: Smithsonian Institution.

582 Zúñiga, Fernando. 2006. Deixis and Alignment - Inverse systems in indigenous languages of the Americas. 583 Amsterdam: Benjamins. 